\title{
AZ ÖNKORMÁNYZATOK GAZDÁLKODÁSA ÉS A FEJLESZTÉSI FORRÁSOK BEVONÁSÁNAK LEHETŐSÉGEI KÖNYVVIZSGÁLÓI SZEMMEL, AVAGY A REFORMOK SZÜKSÉGSZERÜSÉGE
}

\author{
(Opportunities of Local Government Finance from the Point of \\ View of an Accountant or the Necessity of Reform)
}

\section{SZABÓ ISTVÁN}

Kulcsszavak:

önkormányzat reform fejlesztési források vagyongazdálkodás

Az önkormányzati fejlesztési források nagyon sokrétüek és bonyolultak. Ez adódik az önkormányzati forrásszabályozásból és magából a közigazgatási rendszerból. Más a források szabályozása a helyi kisebbségi önkormányzatoknál, a többcélu kistérségi társulásoknál, a megyei önkormányzatoknál, illetve a régióknál. Természetesen a fejlesztési források alakulása összefüggésben van az önkormányzati szektor különbözö szintjeivel, mert külön-külön más feladat-és hatáskörrel rendelkeznek. Alapvetôen az önkormányzati alrendszer felhalmozási jellegü bevételi lehetöségeiböl indultunk ki, nem vizsgáltuk a müködèsi jellegü bevételeket ( $p l$. normativ állami támogatásokat), mert ezek szorosan nem kapcsolódnak a fejlesztésekhez. A fejlesztési források tárgyalásánál nem törekedtünk a teljességre, hanem az általunk legfontosabbnak itélt alternativákat kivántuk bemutatni.

\section{Néhány gondolat az államháztartási rendszerröl, az önkormányzati} szektorról és annak müködéséről

A magyar önkormányzati szektor kiadási struktúráját tekintve átlagosan a GDP 14\%-át teszi ki, bevételei tekintetében pedig 16\%-ot. A fejlett nyugati országokban a kiadási struktúra aránya a GDP-hez viszonyítva $10 \%$ körüli érték.

Az államháztartás önkormányzati alrendszerét 2006-ban 3187 helyi önkormányzat és 2045 települési kisebbségi önkormányzat alkotta. A helyi önkormányzatok könyvviteli mérlegében kimutatott vagyona 2005-ben 9861 milliárd Ft volt, ami 2006-ban 10300 milliárd forintra nőtt. Az önkormányzatok 2002-ben 2570 milliárd Ft, 2006-ban 45\%-kal magasabb összegủ, 3719 milliárd Ft konszolidált költségvetési bevétellel gazdálkodtak.

Az önkormányzati feladatok ellátásában 43 ezer köztisztviselỏ és 395 ezer teljes munkaidőben foglalkoztatott közalkalmazott vett részt (Allami... 2005). Az önkormányzatok 2004. január 1-jén az Önkormányzati törvény (Ötv.) szerint a közszolgáltatások 41,2\%-át költségvetési szervek, 36,2\%-át társas vállalkozások, 19,2\%-át közhasznú szervezetek útján nyújtották (Állami... 2005). Az önkormányzati forrásszabályozás- és támogatási rendszerre jellemző a jövedelemcentralizáció, illetve a 
Szabó István : Az önkormányzatok gazdálkodása és a fejlesztési források bevonásának lehetöségei könyvvizsgálói szemmel, avagy a reformok szükségszerüsége.

feladat, a hatáskör és a felelősség vonatkozásában pedig a decentralizáció. A forrásszabályozás módjában a 2007. évi költségvetés sem hozott érdemi változást, alapvetően az önkormányzatoknál és intézményeiknél a takarékosság, a hatékonyság növelésére tett intézkedések, a forráshiány és bizonyos értelemben a vagyonfelélés tendenciája mutatható ki.

Ahhoz, hogy különbözö önkormányzati szintek eredményesen müködjenek, megfelelő és elegendő pénzügyi forrásra van szükség. Az önkormányzatok abszorpciós képessége a különböző külső forrásokhoz (közösségi támogatások, hitelek, müködő tőke befektetések) való hozzáférés és ezek olyan felhasználási módja, amelynek eredményeként jobb minöségü és/vagy nagyobb mennyiségü kollektív jószág biztositására lesz képes az önkormányzat, és nö az adott önkormányzat vagyona (Vigvári 2005a).

Az önkormányzatok abszorpciós képességét a központi forrásszabályozás döntően befolyásolja, alakítja. Ha ez kiszámítható és átlátható, akkor megteremtődik a tervezés alapvető feltétele. Pontosabban a középtávú tervezésre, a belső kontroll mechanizmusok kiépítettségére és a településfejlesztési támogatási rendszer összeépitésére gondolunk. Fontos követelmény, hogy a helyi választott testületek alkalmazkodni tudjanak az új támogatási mechanizmusok követelményeihez az előkészitett programokkal, saját erő biztosításával. Gondoskodni tudjanak az önkormányzati vagyonról, illetve annak gyarapításáról.

$\mathrm{Az}$ önkormányzati gazdálkodást átláthatóbbá kell tenni, illetve teret kell adni nagyobb érdekeltségi rendszernek. Véleményünk szerint ezek a megfogalmazott igények önmagukban is értelmezhetök, az önkormányzati rendszer múködésének lényege, hogy a helyi társadalom mennyiségileg és minöségileg meghatározott ellátási igényeinek mind magasabb szintủ kielégitése jöjjön létre.

Meg kell azonban jegyezni, hogy a regionális szint finanszírozása alapvetően kormányzati és önkormányzati típusú régiók kialakulásától függ. Söt, a helyi önkormányzatok, a kistérségek és régiók között vannak speciális jogállású és sajátos feladatkört betöltő települések, amelyek finanszírozását nem lehet általános normatívákkal kezelni. Ilyenek például a nagyvárosok és agglomerációs térségeik. Az önkormányzati forrásszabályozási rendszer továbbfejlesztéséhez kutatási témákat és reformirányzatokat fogalmazott meg Péteri (2003).

\section{A fejlesztések eröforrásairól}

A helyi önkormányzatok egyre több közszolgálati feladatot látnak el, ami felemészti bevételeik döntỏ hányadát, egyre kevésbé tudják folyó költségvetési bevételeikböl elöteremteni a közberuházásokhoz szükséges forrásokat. Rechnitzer szerint az önkormányzatok a rendszerváltástól kezdve az elmúlt tíz esztendőben egyre több fejlesztési eröforráshoz jutottak, ami érvényes a területi és a helyi szintre egyaránt (Rechnitzer 2005).

A területi szinten a területfejlesztésekhez kapcsolódó erőforrások találhatók, amelyek nagyságát szükségszerü bővíteni, hiszen a GDP jelenlegi 0,2\%-át kitevő 
Szabó István : Az önkormányzatok gazdálkodása és a fejlesztési források bevonásának lehetöségei könyvvizsgálói szemmel, avagy a reformok szükségszerüsége.

Tér és Társadalom 23. évf. 2009/2. 193-200. p.

TÉT XXIII. évf. 2009 घ 2

Gyors ténykép

195

decentralizált forrásokat a jövőben 1,5-1,8\%-ra kell növelni, gondolva arra, hogy az önrészt biztosítani kell az európai uniós támogatások mellé. Természetesen ehhez szükséges a közigazgatási rendszer átalakitása a közel 3200 települési önkormányzat intézményi integrációjával, sőt az állami tevékenységek területi közvetítő rendszerében is szükségessé válik a reform.

\section{A fejlesztési lehetóségeket meghatározó cél-és címzett támogatások}

A címzett támogatási rendszer az önkormányzatok pénzügyi szabályozásának része, amelynek bevezetésére 1991-ben került sor. Feladata, hogy az Országgyủlés által meghatározott, társadalmilag kiemelt célok megvalósítását részben vagy egészben központi pénzforrásból elősegítse.

A helyi önkormányzatok címzett és céltámogatási rendszerét az 1992. évi LXXXIX. Törvény (Cct.) szabályozza, amely a hatályba lépése óta évente módosult, pontosító elöírásokkal bővült (Deli 2003). Az elmúlt 12 évre visszatekintve megállapítható, hogy a címzett és céltámogatási rendszer a rendszerváltást követő évtized közösségi fejlesztéseinek mozgatórugójává vált. Segítségével ugyanis 1991-2006 között összesen 11109 önkormányzati beruházás kezdődött el és valósult meg, melyek összköltsége 1263 milliárd Ft. Ebböl 792 milliárd Ft a címzett és céltámogatás, 471 milliárd $\mathrm{Ft}$ pedig az önkormányzati saját erő. Ezen belül a céltámogatás segitségével 10238 beruházás 733 milliárd Ft értékben, a címzett támogatás segítségével pedig 871 beruházás 531 milliárd Ft összköltségben valósulhatott meg (Önkormányzati és Területfejlesztési Minisztérium).

Megállapítható, hogy az elmúlt évtizedben e támogatások segítségével kiépült a lakosság széles körét érintő közszolgáltatások rendszere. A céltámogatások esetében a támogatandó célok körét a társadalmilag legfontosabb elvárások alakították, mint az egészséges ivóvíz-hálózat, iskolai tantermek és kollégiumok, települések szennyvízcsatornázása, egészségügyi intézmények gép- és műszervásárlása. A címzett támogatási rendszer pedig forrást teremtett a nagy költségigényú színházi, levéltári, kórházi, jellemzően középfokú oktatási, szociális otthoni beruházásokhoz, amelyeket az érintett önkormányzatok az átlagosnál nagyobb mértékủ központi támogatás nélkül nem tudtak volna megvalósítani. Ezek a támogatások döntési mechanizmuson alapuló támogatások, hiszen a döntés előkészítése és a döntés magas szintủ jogszabályok alapján, nyilvános eljárási rendben történik. A címzett támogatásokról az Országgyúlés, a céltámogatásokról a Kormány dönt.

A céltámogatási rendszer az Ötv. ,alanyi joga" és egyben problémája is. Az önkormányzati rendszer tagoltsága miatt a céltámogatási rendszer folyamatosan változik, ez társulásra ösztönözte az önkormányzatokat (pl. kistelepülések társulása esetén $+20 \%$-os támogatást kaptak).

A fejlesztési források problémája, hogy a tárcák nem alkották meg a stratégiai tervezés elvén alapuló fejlesztéspolitikát, nem számoltak a későbbi üzemelés költségeivel. A céltámogatás keretében csak alapvető fejlesztési célra lehet központi támo- 
Szabó István : Az önkormányzatok gazdálkodása és a fejlesztési források bevonásának lehetöségei könyvvizsgálói szemmel, avagy a reformok szükségszerüsége.

gatást igényelni, és ez meghatározta az önkormányzati beruházások többségét. Arra pályáztak amire céltámogatás igényelhetô. Amennyiben ugyanis a reálisnál több támogatási cél kerül meghatározásra, úgy egy célra kevesebb forrás jut, vagy alacsonyabb lesz a támogatás mértéke.

Az összes központi és egyéb támogatásnál az önkormányzatok többségénél komoly nehézséget okoz a saját erö biztosítása. A saját források szükösségével függ össze, hogy egy projekt megvalósításához több pályázatra van szükség (KAC, VICE és egyéb decentralizált támogatásokra).

A címzett támogatások a nagy költségigényü, 200 millió Ft feletti, térségi feladatellátást szolgáló, kiemelt jelentőségủ beruházások támogatására szolgálnak. Az Ötv. értelmében az Országgyülés dönt a Kormány javaslata alapján, ezért elsősorban ágazati érdekek érvényesülnek. 2004 mérföldkő a társfinanszírozás tekintetében. Lényegében 2004-töl az önkormányzatokat érintő központi és decentralizált támogatások társfinanszírozási és kizárólag hazai forrásból finanszírozható fejlesztéseket szolgálnak. Ezen elöirányzatok közül a legfontosabbak: a céljellegủ decentralizált támogatás (CÉDE), a területi kiegyenlítést szolgáló támogatás (TEKI), a terület- és régiófejlesztési előirányzat (TRFC), a térség- és település felzárkóztatási elöirányzat (TFC), a környezetvédelmi alap elöirányzat (KAC) és a vízügyi elöirányzat (VICE), 2005-től a települési hulladék közszolgáltatás fejlesztéseinek támogatása (TEHU), a települési önkormányzati szilárd burkolatú belterületi közutak burkolat felújitásának támogatása (TEUT), 2006-tól pedig a leghátrányosabb helyzetủ kistérségek felzárkóztatásának támogatása (LEKI).

Lados szerint 2005-2007 között az összegében jelentősen lecsökkentett teljes céltámogatási keret elosztását a regionális fejlesztési tanácsok végzik (Szigeti 2006). A forráselosztás decentralizálásának indoka, hogy a döntés közelebb kerüljön a forrást felhasználó önkormányzathoz.

\section{Az önkormányzatok fejlesztése hitellel}

A helyi önkormányzatokról szóló 1990. évi LXV. törvény lehetőséget biztosít hitel felvételéhez és kötvénykibocsátáshoz azzal a korláttal, hogy e mủveleteket az önkormányzatok korrigált saját bevételük $70 \%$-áig tehetik meg. Természetesen a hitelfelvételi korlát meghatározása, illetve számítása (kezességvállalások, garanciák stb.) számos problémát vetnek fel, amivel most nem kívánunk foglalkozni.

Az önkormányzatok létrejöttekor, 1990-ben a hitelállomány átlagosan az éves költségvetés 1\%-a körül alakult, 2004-ben az éven túli hiteleket leszámítva megközelítette az 5\%-ot, megoszlása pedig hektikus volt. Ennek okát Keményné abban látja, hogy a mintegy 3200 önkormányzat közül csak néhány száz alkalmas a hitelfelvételre (Keményné Koncz 2005a). Döntö részük azért nem, mert a saját bevételük alapján jogszabályi korlátba ütközik a hitelfelvétel. A hitelképes önkormányzatok viszont fejlesztési feladataikat egyre több hitelböl finanszírozzák, a hitelállomány koncentrációja nagyon magas. 
Szabó István : Az önkormányzatok gazdálkodása és a fejlesztési források bevonásának lehetöségei könyvvizsgálói szemmel, avagy a reformok szükségszerüsége.

Tér és Társadalom 23. évf. 2009/2. 193-200. p.

TÉT XXIII. évf. 2009 - 2

Gyors ténykép

197

A nemzetközi tapasztalatok egyrészt azt mutatják, hogy az önkormányzatok eladósodottsága a beruházásaik miatt következett be, másrészt, hogy az önkormányzatok hosszú lejáratú hitelt csak és kizárólag beruházásokra vesznek fel. Aranyszabály az is, hogy ezeket a forrásokat nem szabad folyó kiadásokra felhasználni. A magyar önkormányzati rendszer forrásbevonó képességét és az önkormányzati hitelpiac helyzetét vizsgálta Vígvári a SWOT elemzés módszerével (Vigvári 2005b). Lehetséges szabályozási megoldásokat javasol a tervezhetőségre, a méretgazdaságosságra, a központi kontroll szigorítására, a garancia-intézmények és eszközök új rendszerére, az adósságregiszter bevezetésére, az eredményszemléletủ pénzügyi beszámolórendszer bevezetésére, a tervezési gyakorlat korszerüsítésére, a központi beruházási transzferek reformjára, a piackonform kincstári szabályozásra.

A teljesség igénye nélkül néhány külső forrás ismertetése: Az Önkormányzati Infrastruktúra Fejlesztési Hitelprogram, melynek célja az önkormányzatok alap és kötelező feladatainak ellátását szolgáló beruházások kedvezményes kondíciójú hitellel való biztosítása. Az Európai Beruházási Bank hitelkerete: a környezetvédelem, az infrastruktúra, a tudásközpontú társadalom fejlesztése, az oktatás és az egészségügy területén használható fel.

\section{PPP projektek az önkormányzati területen}

Az önkormányzatok által ellátandó feladatokból lehet-e bizonyos közszolgáltatási feladatokat (víz- és csatorna beruházás, bérlakásépítés, sportcsarnok építése stb.) múködtetni PPP formában? A kérdésre a válasz igen, ha biztosítva van a megfelelö jogi környezet.

A megvalósuló beruházások esetében elengedhetetlen követelmény a projekt jogi hátterének vizsgálata, összhangja az európai uniós jogszabályokkal és a hazai jogi szabályozással. Az Európai Unió maasttrichti kritériuma megköveteli, hogy hazánk államháztartási hiánya ne haladja meg a GDP 3\%-át, továbbá az államadósság nem lehet több a GDP 60\%-ánál. Annak érdekében, hogy ezeknek a kritériumoknak megfeleljen az állam, vissza kell szorítania az államadósságból finanszírozott közcélú beruházásokat. Ez indokolta a PPP konstrukció kialakulását és elterjedését.

A PPP konstrukció egyik fajtája a koncesszió, ahol az önkormányzat a tevékenységi köröket a koncessziós szerződés keretében átengedi az arra jogosult koncessziós társaság részére. A koncessziós társaság jogosult az önkormányzati törzsvagyonhoz tartozó egyes vagyontárgyak birtoklására, használatára és hasznok beszedésére, azonban a koncessziós társaság ezt a használati jogát nem idegenítheti el, apportként sem adhatja más gazdasági társaságba. 
Szabó István : Az önkormányzatok gazdálkodása és a fejlesztési források bevonásának lehetöségei könyvvizsgálói szemmel, avagy a reformok szükségszerüsége.

Tér és Társadalom 23. évf. 2009/2. 193-200.,p.

\section{Néhány gondolat a régió eröforrásairól a fejlesztési források tekintetében}

A régióknak három alapvetö funkciójuk van, helyi önkormányzati szintként múködnek, területfejlesztési célokat látnak el és államigazgatási és közigazgatási jogkörrel rendelkeznek. A hármas funkció ellátásához a régió finanszírozási rendszerének költségvetési szempontból semlegesnek kell lennie.

A feladatok decentralizációjával és átszervezésével a múködés hatékonyságára kell törekedni, az önkormányzati rendszer rendelkezésre álló bevételeit külső forrásokkal kell bóvíteni úgy, hogy az a területfejlesztés érdekeit szolgálja. A regionális önkormányzatok költségvetési rendszerének kialakításakor az európai és a hazai hagyományokra támaszkodó modern önkormányzati finanszírozási elveket kell kidolgozni. Péteri szerint a regionális önkormányzatok bevételei és kiadásai, azaz a regionális költségvetés egyensúlyban tarható (Péteri 2003). Természetesen a fejlesztési források fedezete a megosztott bevételek, az állami támogatások és a hitelbevételek formájában jelentkezne. A magyar régiók várható uniós finanszírozását (ERDF, EMOGA, ESZA, HOPE) a várható célkitüzések tekintetében részletesen bemutatja Pogátsa (2005) tanulmánya.

\section{Saját bevétel és felelös vagyongazdálkodás, mint lehetséges fejlesztési forrás}

Az önkormányzati fejlesztések egyik jellegzetes forrása a vagyonhasznosításból képződő források és az osztalékbevételek.

Az osztalékbevételekböl származó forrás felhasználására törvényi kötelezettség nincs, mértéke az elmúlt évtized során egyre csökkent. Ennek egyrészt az az oka, hogy a települési önkormányzatok állandó jelleggel forráshiánnyal kủzdenek, így a legmobilizálhatóbb értékpapír állományuktól szabadulnak meg először. Másrészt az Áht. szigorúan szabályozza a települési önkormányzatok gazdasági társaságokban való részvételét az üzletrész mértéke és a kockázatviselés tekintetében.

Az önkormányzati vagyongazdálkodással kapcsolatban Varga szerint érdemes lenne egy felhalmozási pénzalapot létrehozni (Varga 2005). Az önkormányzati vagyongazdálkodás hosszú távú érdekeinek érvényre juttatása lényegében megoldható lenne. Ezt azonban csak bizonyos direkt intézkedésekkel lehet elérni, amely az önkormányzati gazdálkodás szabadságát korlátozza, viszont a tulajdonosi érdekérvényesítés alátámasztását szolgálja. Az alapban halmozódna fel az értékcsőkkenési leírás, a vagyongazdálkodásból származó minden bevétel. Ezek együttesen finansziroznák a vagyonfejlesztést, a pályázatok önerejéhez forrást tudnának biztosítani. Lényegében ez a pénzalap képezné a felelős vagyongazdálkodás intézményes pénzügyi garanciảját, és önkormányzati rendeleti szintre emelné a pályázatok önerejéhez szükséges forrás biztosítását. A rendeleti szabályozást szükségesnek tartjuk abból 
Szabó István : Az önkormányzatok gazdálkodása és a fejlesztési források bevonásának lehetöségei könyvvizsgálói szemmel, avagy a reformok szükségszerüsége.

Tér és Társadalom 23. évf. 2009/2. 193-200. p.

TÉT XXIII. évf. 2009 - 2

Gyors ténykép

az aspektusból, hogy ezeket a forrásokat ne müködési jellegủ kiadásokra fordítsák a települési önkormányzatok, hanem újbóli beruházásokat generáljanak. Gondolatként felvetjük, hogy a települési önkormányzatok feladat- és hatásköréhez kapcsolódóan a jelenlegi vagyongazdálkodás hatékony-e, a törvényi szabályozás rugalmas-e stb.?

\section{Összefoglalás helyett az alábbi záró gondolatok és ajánlások}

A központi forrásszabályozást kiszámíthatóvá és egyszerübbé kell tenni.

A fejlesztési támogatások rendszerét harmonizálni kellene az NFT II-ben kiírásra kerülö célok önrész-támogatásaival.

Felhalmozási pénzalap létrehozása a vagyongazdálkodás intézményes pénzügyi garanciája lehet és önerő a pályázatokhoz.

$\mathrm{Az}$ önkormányzati szektor hitelezésével kapcsolatban elvárható lenne, hogy a szabályozó rendszer évenként ne módosuljon, az új kötelező feladatokat csak teljes mértékủ állami hozzájárulás mellett vállalhassák az önkormányzatok, illetve az ÖNHIKI-s önkormányzatok valós helyzetét tényszerủen be kellene mutatni. Újra kellene gondolni az államháztartás egésze és az önkormányzati alrendszer viszonyát a központosított bevételek elosztása tekintetében.

Biztosítani kellene a fejlesztési tevékenységnek és a vagyongazdálkodásnak az átláthatóságát, értékelését.

Az önkormányzati feladatellátás módosult szervezeti rendjére tekintettel gondoskodni kellene a konszolidált beszámoló készítéséről.

A forrásszabályozásnak igazodnia kellene a feladatok önkormányzati kategóriák szerinti differenciálásához.

Fokozatosan ki kell alakítani az üzemgazdasági szemléletủ gazdálkodást.

Az átlátható fejlesztési támogatási rendszer keretében egy önkormányzati beruházás csak egyféle támogatásban részesüljön, mértéke az önkormányzatok jövedelemtermelő képességétől függjön.

Át kellene gondolni újra a koncessziós szabályokat a PPP vonatkozásában. A fejlesztési források felhasználását nem kíséri folyamatos, teljesítményelvü, eredményességet és hatékonyságot mérő, a fejlesztési célok értékelésére képes hatékony pályázati monitoring.

Rechnitzer (2007) szerint az önkormányzati szervezeti rendszerben célszerủ a város menedzsmentintézményét létrehozni. Ez a szervezeti modell összefogja az önkormányzat fejlesztési aktivitásait, azokat képviseli a politikai döntéshozóknál és a hivatali rendszeren keresztül. Egy fejlesztési központ, egy kapcsolati és kommunikációs csatorna, egy felelősségi rendszer képes csak a fejlesztéseket, azok összetett lépéseit és hatásait átfogni. 
Szabó István : Az önkormányzatok gazdálkodása és a fejlesztési források bevonásának lehetőségei könyvvizsgálói szemmel, avagy a reformok szükségszerüsége.

\section{Irodalom}

Állami Számvevőszék jelentése a helyi és a helyi kisebbségi önkormányzatok gazdálkodásának átfogó ellenörzésérỏl. (2005) - Önkormányzati Tájékozató. 10.3-57. o.

Deli E. (2003) A helyi önkormányzatok fejlesztési lehetóségeit meghatározó támogatások, különös tekintettel a címzett és céltámogatások jövőjére. Kézirat a BM IDEA Program Finanszírozási Munkacsoportja részére.

Illés I. (2005) Önkormányzati finanszirozás és adózás nemzetközi összevetésben. Tanulmány a BM IDEA Program Finanszírozási Munkacsoportja részére.

Keményné Koncz I. (2005a) Hitelképesek-e ma az önkormányzatok? Belső döntés-előkészítő anyag. Raiffesein Bank, Budapest.

Keményné Koncz I. (2005b) PPP projektek önkormányzati területen. - Vígvári A. (szerk.) Félúton: tanulmányok a helyi önkormányzatok finanszírozási rendszerének továbbfejlesztési lehetöségeiröl. TIMP Kft., Budapest. 169-184. o.

Lados M.-Kovács G. (2007) A településfejlesztés finanszírozási rendszere, pénzügyi szabályozása. Rechnitzer J. (szerk.) Település és fejlesztés. Közigazgatási olvasmányok. KSZK ROP 3.1.1. PROGRAMIGAZGATÓSÁG, Budapest. 143-162. o.

Péteri G. (2003) A régió erőforrásai. Pénzügyi szempontok a regionális önkormányzatok kialakításához - Pénzügyi Szemle. Július. 640-653. o.

Péteri G. (2005) Önkormányzati forrásszabályozás: ideák és javaslatok. Kézirat a BM IDEA Program Finanszírozási Munkacsoportja részére.

Pitti Z. (2004) Az önkormányzatok pénzügyi finanszírozásának modernizációja. Vitaanyag. - Pénzügyi Szemle. 4. 348-365. o.

Pogátsa Z. (2005) A magyar régiók várható uniós finanszirozása a következó pénzügyi perspektiva idöszakában. Tanulmány a BM IDEA Program Finanszírozási Munkacsoportja részére.

Rechnitzer J. ([2005) Hogyan tovább regionális politika? Tanulmány a BM IDEA Program Finanszírozási Munkacsoportja részére.

Rechnitzer J. (szerk.) (2007) Település és fejlesztés. Közigazgatási olvasmányok. KSZK ROP 3.1.1. PROGRAMIGAZGATÓSÁG, Budapest.

Szigeti (szerk.) (2006) Terület és településfejlesztési ismeretek. Magyar Közigazgatási Intézet, Budapest.

Varga I. (2005) Gondolatok az önkormányzatok vagyongazdálkodásának reformjáról. Tanulmány a BM IDEA Program Finanszírozási Munkacsoportja részére.

Vígvári A. (2005a) Forrás-abszorpció és forrásszabályozás. Vígvári A. (szerk.) Félúton: tanulmányok a helyi önkormányzatok finanszirozási rendszerének továbbfejlesztési lehetöségeiről. TIMP Kft., Budapest. 185-206. o.

Vígvári A. (2005b) Az önkormányzatok hitelfelvétele. Vígvári A. (szerk.) Félúton: tanulmányok a helyi önkormányzatok finanszirozási rendszerének továbbfejlesztési lehetöségeiröl. TIMP Kft., Budapest. 151-168. o. 